\title{
Infundibular cysts jeopardize reproduction in the camel (Camelus dromedarius)
}

\author{
M. M. Al-Eknah and A.M. A. Ali \\ Camel Research Centre, College of Veterinary Medicine and Animal Resources, \\ King Faisal University, P.O. box 1757, Al-Ahsa 31982, Saudi Arabia
}

\begin{abstract}
It has been proposed that infundibular cyst, which is a dilatation of the cranial part of the infundibular wall of the uterine tube, adds a new factor for infertility in the camel. 650 genital tracts from camels affected with infundibular cysts have been collected from three abattoirs throughout 10 years period starting October 1990. In addition, 35 female camels admitted in the Veterinary Teaching Hospital, King Faisal University, suffering from infertility, were diagnosed by ultrasound array scanner to have infundibular cysts. The cyst wall composed mainly of fibrous connective tissue and lined by low columnar epithelium with vacuolated appearance and striated border. The microorganism isolated from the cyst content was identified as Aeromonas hydrophilla according to their biochemical properties. This study strengthen the proposal that infundibular cysts reduce fertility in the camel.
\end{abstract}

Key words: infundibular cysts, genital tract, female camel, Saudi Arabia.

\section{Introduction}

Saudi Arabia is considered to have the fourth highest camel population in the Arabian world; with an estimated population of one million. Ahmed (1994) and Tibary and Anouassi (1997) described a cyst-like structure at the cranial part of the genital tract in female camels as "hydrobursitis". However, according to our previous study (Ali et al, 1992), the characteristic features of the cyst-like structure formed at the same site proved to be "infundibular cyst". The histopathology of the cyst wall consisted of fibrous connective tissue and smooth muscle, and lined by low columnar epithelium. This was similar to the mucosal lining of the uterine tube (Columnar epithelium). On the other hand the ovarian bursa was lined by mesothelial cells. Therefore, this condition cannot be called hydrobursitis. Tibary and Anouassi (1997) claimed that this condition has not been reported in Saudi Arabia.

\section{Materials and Methods}

\section{Collection of specimens}

Five thousand genital tracts of female camels (Camelus dromedarius) have been randomly collected from three different abattoirs in Saudi Arabia; Al-Ahsa, Riyadh and Jeddah. The investigation was carried out throughout 10 years period starting from October 1990. Six hundred and fifty cases $(13 \%)$ with cyst-like formations at upper genitalia were recorded and subjected immediately to thorough examination. Age of the camels ranged between 12-23 years.

Animals

Thirty five female cases out 152 female camels $(23 \%)$ admitted in the Veterinary Teaching Hospital, King Faisal University, during the period from 15 January to 15 April 2001, suffering from infertility, were suspected by rectal examination to have infundibular cysts. Therefore, the suspected animals were subjected to gynaecological examination using the ultrasound array scanner (HS - 1201 V, Honda Electronics, Japan). The scanning procedure was carried out with the animal in sternal recumbancy. The ultrasound probe $(7.5 \mathrm{MHz})$ was introduced into the rectum and guided by the operator's hand over the uterine body, horns and later the oviduct and ovarian region. The probe was then forwarded cranially into the abdominal cavity and moved right and left over the cyst-like structure. 
Bacteriological investigations

The surfaces of one hundred and thirty cysts were carefully cleaned using $70 \%$ alcohol and allowed to dry. The surface was seared by a red, hot spatula. Disposable 10 $\mathrm{ml}$ plastic syringes were used to withdraw $10 \mathrm{ml}$ of the cyst content aseptically. A new drops were plated directly onto $10 \%$ sheep blood agar, MacCondey`s agar and into alkaline peptone water (APW) and heart infusion broth (HIB) (Shread et al, 1981). The rest of the samples were transferred to sterile centrifuge bottles and centrifuged at $5,000 \mathrm{rpm}$ for 15 minutes at $4{ }^{\circ} \mathrm{C}$. The supernatant was decanted and deposits cultured in similar media as mentioned above. The incubation period was carried out anairobically at $30{ }^{\circ} \mathrm{C}$ for 24 hours. When growth was obtained only in APW and HIB, subcultures were reincubated for 7 days before they were regarded as negative. The isolates were identified according to Cowan (1981), Carter (1984), and Krieg and Holt (1984). Sensitivity tests were performed with Oxoid discs. The toxin was prepared from HIB. The medium used was incubated in a water bath for 10 hours with vigorous shaking. The method of haemolytic activity and enterotoxin assays, in addition to pathogenisity for mice and delayed permeability factor in rabbit skin were done according to Ali et al (1992).

\section{Histopathological investigations}

Samples for histopathology were taken 30 minutes after slaughter form different parts of the cyst wall, infundibulum, cranial part of the uterine tube and ovarian bursa. Tissues were fixed in Bouin's fluid, processed in paraffin and sections were stained with haematoxylin and eosin and Van Gieson`s stain.

\section{Results}

Gynaecological examination

Infundibular cysts with variable sizes were palpated rectally. Tension put on the genital tract depended on the size of the infundibular cyst. Small sized cysts $(<5 \times 5$ $\mathrm{cm}$, length $\mathrm{x}$ width) palpated in 5 animals $(14.3 \%)$ were retracted easily by the operator's hand. Medium sized cysts $(5 \times 5$ $\mathrm{cm}$ to $20 \times 10 \mathrm{~cm}$ ) palpated in 11 animals $(41.4 \%)$ were retracted with difficulty. However, the circumference of the large sized cysts $(>20 \times 10 \mathrm{~cm})$ were not reached and thus, it was not retracted (Table 1). Twenty two cases $(62.9 \%)$ were unilateral. However, the scanner gave varying shades of grey within the black region (anechgenic to hypoechogenic) appearance of the cyst content (Fig.1 and 2).

Table 1. Number and Percentage of infundibular cysts with different sizes

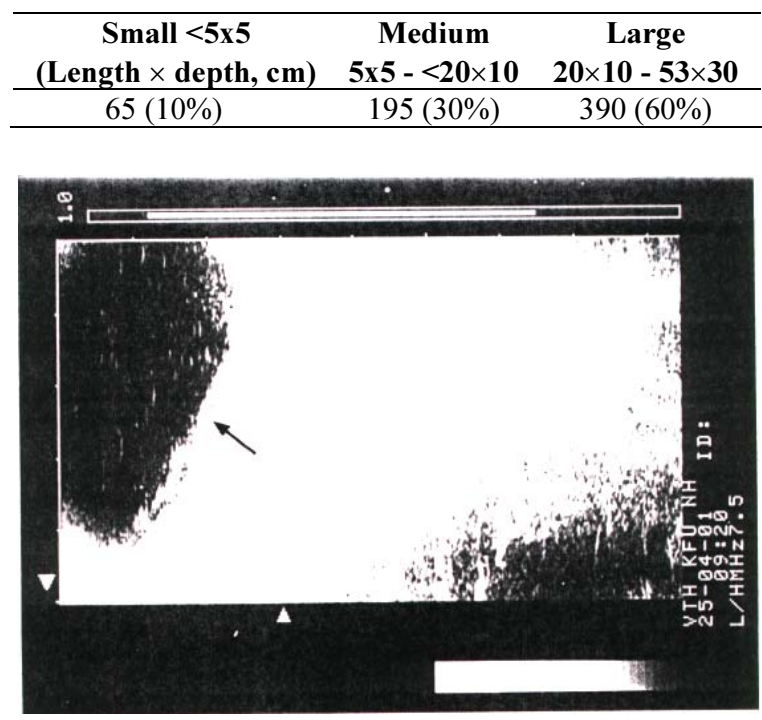

Fig.1. Ultrasound images of an infoundibular cyst appearing anechogenic 


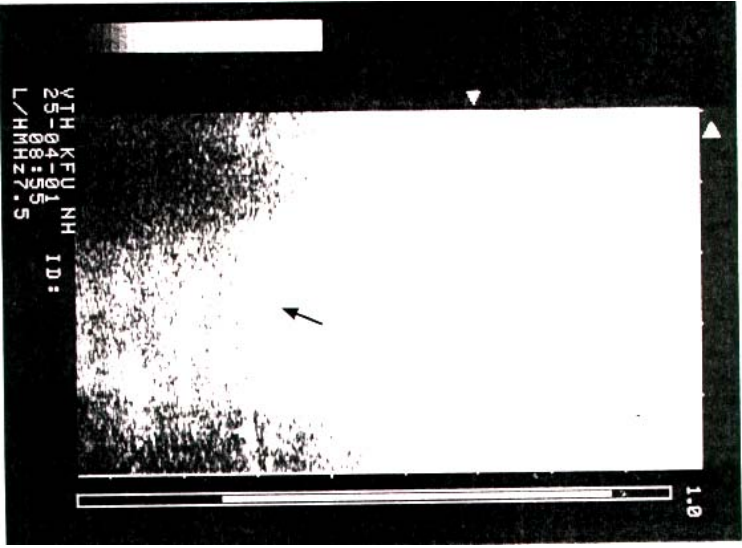

Fig.2. Ultrasound images of an infoundibular cyst appearing hyperechogenic

Morphological description

The apparently normal uterine tube was soft with tortuous shape and enclosed in the mesosalpinx which arises from the lateral surface of the mesovarium. It's length ranged between 22.5 and $30 \mathrm{~cm}$. The funnel-shaped infundibulum (7-10 cm width) had longitudinal folded mucous membrane which converged towards the abdominal opening of the tube with the free margin to form the fimbrae. The ampullary region was flabby with a relatively wider lumen.

The cyst-like structures in all cases examined formed a cranial dilation of the infundibulum which closed the infundibulum. The ovarian bursae had 5-12 $\mathrm{cm}$ depth and were formed between the mesosalpinx laterally and the mesovarium and ovary medially. The bursa was crossed by fibrous tissues. The ovary was located within the ovarian bursa. Therefore, the cysts were called "Infundibular cysts" (Fig.3, 4 and 5). The cyst size ranged between $4 \times 2.8 \mathrm{~cm}$ (length $\mathrm{x}$ width) to $92 \mathrm{x}$ $53 \mathrm{~cm}$.

In $64.6 \%$ (420 cases), the ovaries with the bursae were encapsulated in the cysts. The cysts were either unilateral $(62 \%)$ or bilateral (38\%).

The content of the cysts was fluid with different colours (Clear, yellowish, light or dark brown) and consistency (serous, semifluid, muddy or turgid). The fluid amount ranged between $3 \mathrm{ml}$ (In the smallest cyst) to $25200 \mathrm{ml}$ (In the largest cyst).

\section{Histopathological Findings}

The cyst wall consisted of fibrous connective tissue and smooth muscle, and lined by low columnar epithelium. The columnar epithelium had a vacuolated appearance and an apparently striated border with surface globules. The mucosa of the cranial part of the uterine tube was distinctly folded and lined by similar columnar epithelium with centrally placed nuclei. The cyst content showed many free pinkish globules with a homogenous eosinophilic material containing aggregates of bacilli..

\section{Bacteriological Findings}

Fluid of $70 \%$ (91) of the infundibular cysts gave pure growth of a single type of colonies. The colonies were greyish white, translucent, moist, circular and flat with either $\alpha$ or $\beta$-haemolysis. The size of the colonies increased through further incubation at room temperature reaching $6 \mathrm{~mm}$ in diameter. The colonies turned into light green with age. The organisms were identified as Aeromonas hydrophilla according to their biochemical properties.

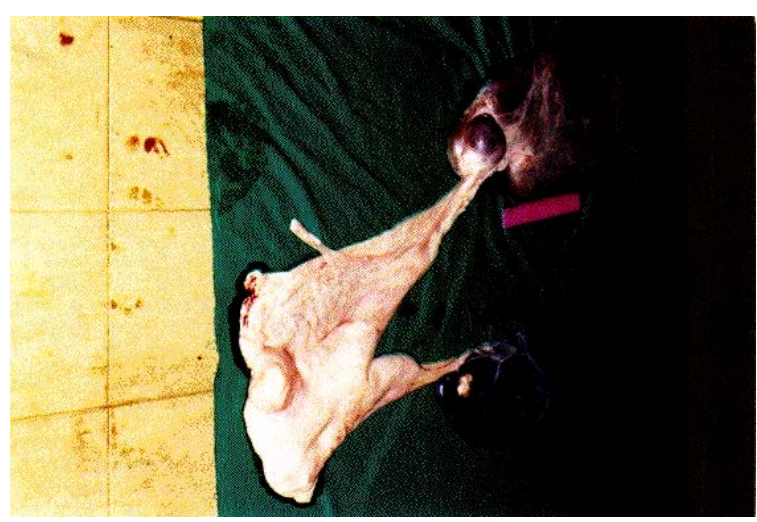

Fig. 3. Bilateral infundifular cysts. Note the enclosed right ovary. 


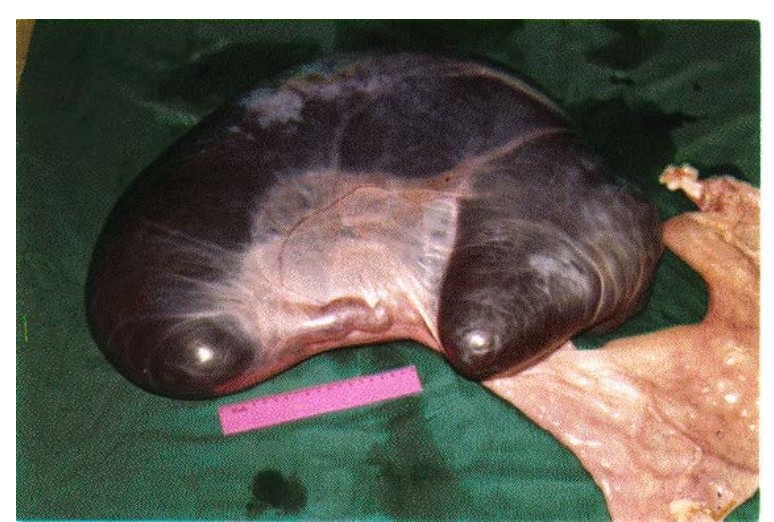

Fig. 4. Unilateral infundifular cyst. Note the blockage of the Fallopian tube.

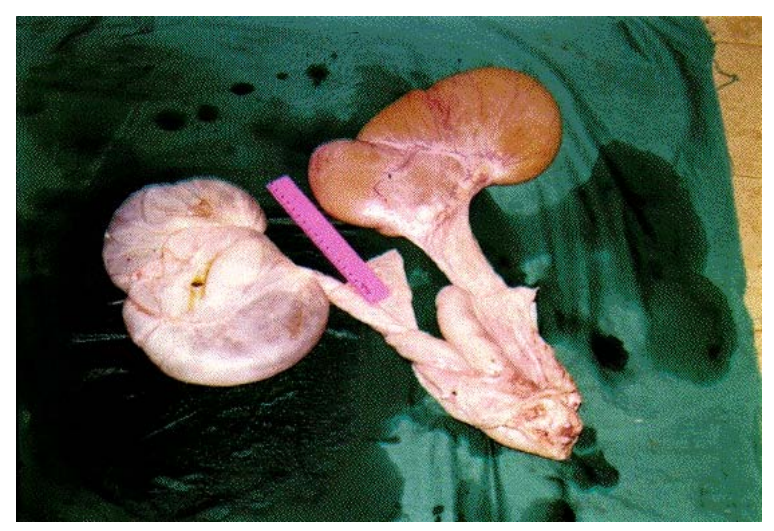

Fig. 5. Bilateral infundibular cysts with different colours and consistency.

\section{Discussion}

Hundreds of female camels are daily slaughtered in different regions all over Saudi Arabia. The vast majority of slaughtered camels are of indigenous types. The described morphological and histopathological structures of the cysts proved that they were dilatation of the cranial part of the infundibular wall, hence they were called "infundibular cysts".

The prevalence of infundibular cysts was fairly high in abattoir's specimens (13\%) and among the infertility cases admitted in the Veterinary Teaching Hospital, Saudi Arabia $(23 \%)$. The future studies should concentrate on the source of infection.

The present study demonstrates the epidemiological importance of Aeromonas hydrophila as a cause of infundibular cysts.
Species of the genus Aeromonas have long been recognized as pathogen in amphibians (Burgemeister, 1974) and fish (Hazen et al, 1978), with wide distribution in aquatic environment (Kaper et al, 1981). The organism was isolated form camel intestine in association with Clostridium perfringens type A and Clostridium sordellii (Gameel et al, 1986). The fluid accumulated in the cysts were due to the toxin released by the organism. This is consistent with the findings of Asao et al, (1984), and Turnbull et al, (1984) when the same toxins have been proved to cause accumulation of fluids.

\section{References}

Ahmed, Y.F. 1994. Some morphological and histopathological studies on the reproductive system of she-camel at Saudi Arabia. Fifteenth Annual Meeting of Saudi Biological Society, Makkah Al-Mukarramah, Saudi Arabia.

Ali, A. M. A., S. M. El-Sanousi, M. M. AlEknah, A. A. Gameel, E. A. Dafalla, Y. M. Homeida and Y. M. Radwan, 1992. Studies on the infundibular cysts of the uterine tube in camel (Camelus dromedarius). Revue Ělev. Méd. Vet. Pays trop., 45, 243-253.

Asao, T.A., Y. Kinoshita, S. Kozaki, T. Uemura and G. Sakaguchi.1984. Purification and some properties of Aeromonas dydrophila haemolysin. Infec. Immun., 46, 122-127.

Burgemeister, R., 1974. Probleme der Dromedarhaltung und zucht in Sudtunesien. Thesis, Justus Liebing University, Giessen, West Germany,

Carter, G.R. 1984. Diagnostic procedure in veterinary bacteriology and mycology. 
4th ed. Charles C. Thomas Publisher, Sprigfield, Illinois, USA.

Cowan, S.T. 1981. Manual for the identification of medical bacteria. 2nd ed., The University Printing Hours, Cambridge, England.

Gameel, A. A., S. M. El-Sanousi, B. Musa and E. E. El-Owani. 1986. Association of some pathogenic bacteria with haemorrhagic enteritis in camels. Small Ruminant and Camel Group, SRC 12 ILCA, 50-55.

Hazen, T.C., C. B. Fliermans, R. B. Hirsch and G. W. Esch. 1978. Prevalence and distribution of Aeromonas dydrophila in the United States. J. Appl. Envir. Microbiol., 36, 731-738.

Kaper, N.R., H. Lockman, R.R. Colwell and S. W. Joseph. 1981. Aeromonas dydrophila: Ecology and toxigenicity of isolates from an estuary. J. Appl. Bacteriol., 50, 359-377.

Krieng, N. R. and J. G. Holt. 1984. Bergey`s manual of systematic bacteriology, Vol. 1, Williams and Wikins, Baltimore, USA.

Shread, P., T. J. Donov and J. V. Lee. 1981. A survey of the incidence of Aeromonas in human faeces. Soc. Gen. Microbiol. Q., 8, 184.

Tibary, A. and A. Anouassi. 1997. Theriogenology in camelidae. Veterinary Research Center, Abu Dhabi, UAE.

Turnbull, P.C., J. V. Lee, M. D. Miliotis, S. Van De Walle, H. J. Koornhof, L. Jefery and T. Bryant. 1984. Enterotoxin production in relation to taxonomic grouping and source of isolation of Aeromonas Species. J. Clin. Microbiol., 19, 175-18. 